\title{
ISOLATION AND STUDY OF THE BIOLOGICAL PROPERTIES OF NON-ONCOGENIC CHICKEN HERPES VIRUSES OF MAREK'S DISEASE
}

\author{
R. HALOUZKA ${ }^{1}$ and V. JURAJDA ${ }^{2}$ \\ Department of Pathological Morphology ${ }^{1}$, Clinic of Avian Diseases ${ }^{2}$, University of Veterinary
} Science, 61242 Brno

Received September 25, 1991

\begin{abstract}
Halouzka R., V. Jurajda: Isolation and Study of the Biological Properties of Non-Oncogenic Chicken Herpes Viruses of Marek's Disease. Acta vet. Brno, 61, 1992: 43-49.

The report deals with cytolytic changes in the lymphoid organs of Brown Leghorn chickens infested experimentally with field isolates of non-oncogenic chicken viruses of $M_{i}$ rek's dise se (MD) and with the value of these changes for evaluation of the pathogenicity of Marek's s disease virus(MDV). $M D V$ isolates $M$ and $K$ were administered to 2-day old cl $i$ ks in different doses $\left(10^{2}, 10^{3}\right.$ and $10^{4} \mathrm{PFU}$ per chick). Ten birds of each group were sacrificed and subjected to pathomorphological examination at 1,2, 3 and 5 weeks $p$. i. Samples for histopathological examination were taken from lymphoid organs, skin, peripheral nerves and gonads. Cytolytic changes in the lymphoid organs were assessed quantitatively using immunosuppression degrees of 0 to 4 .

In addition to MD-specific proliferative changes the two MDV isolates produced cytolytic changes in the lymphoid organs. Isolate. $M$ proved more virulent from the viewpoint of induction of lymphoproliferative changes but exerted weaker cytolytic effects. Isolate $\mathrm{K}$, on the other hand, produced only minute transitory lymphoproliferative changes and more pronounced cytolytic lesions in the lymphoid organs.

Cytolytic changes in the lymphoid organs are regarded as a criterion of the pathogenicity of the two MDV isolates and as one of possible causes of the immunosuppressive state.
\end{abstract}

Brown Leghorn chickens, non-oncogenic MDV isolates, pathogenicity, immunosup-
pression

The main factors underlying the final outcome of infection with Marek's diesase virus (MDV) are viral strain, dose, and genotype and immune status of the host (Calnek et al. 1986).

MDV strains are known to vary in their pathogenic potential and oncogenicity for the susceptible host. There exist highly virulent strains that are oncogenic even for vaccinated poultry, exert severe immunosuppressive effects and may result in considerable death losses among chickens in the first phases of infection (Witter et al. 1980). Other strains cause a high incidence of visceral or neural lymphomas and some other strains are responsible mainly for neural lymphoproliferation. Moderately oncogenic strains produce only minimal lesions in very susceptible poultry and some other strains are non-oncogenic. The characteristics of MDV strains that determine their pathogenicity, oncogenicity and immunosuppressivity have not been fully disclosed ( $\mathrm{Pay}$ e 1985).

"Non-oncogenic strains induce only minute microscopic lymphoproliferative changes and antibody production without clinical signs of disease (S chat 1985). The fact that strains of low oncogenicity cause less damage to lymptoid organs than highly oncogenic strains suggests that oncogenicity is determined by virus-induced immunosuppression (Payne 1985). Morphological changes of lymphoid organs as substrates of immunosuppression of the body after infection with nononcogenic MDV strains have not been described in detail in the relevant literature to date. 
The present report is a continuation of our previous studies on the biological properties of non-oncogenic chicken herpes viruses of $M D$ (Jurajda an Halouzka $1991 \mathrm{a}, \mathrm{b}$ ). Its object is to assess and compare cytolytic changes in the lymphoid organs of susceptible chickens after experimental infection with $M D V$ isolates $M$ and $K$ and determine their pathogenicity.

\section{Materials and Methods}

The isolation of MDV isolates $M$ and $\mathrm{K}$ used in the present study and their in vitro characteristics were described in a previous report (Jurajda and Halouzka 1991 a). Their in vivo characteristics were also described previously (Jurajda and Halouzka $1991 \mathrm{~b}$ ).

One and the same experimental design was used with both MDV isolates ( $M$ and $K$ ). Each of them was administered intramuscularly to Brown Leghorn (BrL) chicks (Biggs and Payne 1963) on the 2nd post-hatching day in the form of a cell suspension in doses of approximately $10^{2}$, $10^{3}$ and $10^{1} \mathrm{PFU}$ per bird in $0.2 \mathrm{ml}$ volumes of infectious inoculum. The experimental chicks were divided into 3 groups according to the infectious dose. The fourth group served as controls.

Ten birds of each group were sacrificed and subjected to pathomorphological examination at $1,2,3$ and 5 weeks p. i. Samples for histopathological examination were taken from thymus, bursa of Fabricius (BF), spleen, skin, peripheral nerves ( $\mathrm{n}$. ischiadicus and plexus brachialis) and gon ds. After fixation in $10 \%$ aqueous neutral solution of formaldehyde they were processed using the routine paraffin technique and stained with haematoxylin and eosin; in indicated cases staining with luxol blue and Giemsa stain was adopted.

Cytolytic changes in the lymphoid organs were assessed quantitatively using immunosuppression ( $\mathrm{Si}$ ) degrees of 0 to 4 . For total evaluation of the regressive morphological changes, index of immunosuppresion (Is) was computed from the ratio of sum of total Si degrees in the individual chickens to the number of chickens examined. Morphological criteria used in evaluating the immunosuppression were described previously (Halouzka and Jurajda 1991). The immunosuppression indices obtained in the chickens infected with different infectious doses were averaged and presented graphically.

\section{Results}

During the 5-week observation period no clinical signs of disease were observed and no deaths occurred. Macroscopic and microscopic examination of the organs revealed no changes in the controls and various degrees of spleen enlargement in infected chickens in both experiments.

\section{Infection with MDV Isolate $M$}

Microscopic MD-specific lesions were diagnosed in the skin of $27(22.7 \%)$ chickens, $\mathrm{n}$. ischiadicus of $12(10.1 \%)$ chickens, plexus brachialis of $4(3.4 \%)$ chickens, and in the gonads of $8(6.7 \%)$ chickens. Examination of a total of 833 tissue samples from infected chickens detected MD-specific microscopic changes in $6.1 \%$ of the samples and in $33.6 \%$ of the infected birds.

Cutaneous changes were characterized by perivascular and perifollicular lymphoid cellulization. Changes in the nerves were located intraneurally and corresponded to type C changes; a frequent finding was perineural location of lymphoproliferative changes. In the testes, analogous changes were observed under the tunica albuginea, and in the ovaries in the spongious stroma of the upper cortical layer. With the higher infectious doses the development of lymphoproliferative changes occurred earlier and their incidence and intensity in the organs were higher.

The incidence and dynamics of regressive changes in the $\mathrm{BF}$ are presented graphically in Fig. 1.

The changes having the character of cytolysis of lymphoid and dentritic reticular cells with subsequent inflammatory reaction in the BF germinal centres, and less frequently in the cortex of lymphoid follicles, were classified, for the most 
part, as $\mathrm{Si}$ degrees 1 and 2 and in a few solitary instances as $\mathrm{Si}$ degree 3. These changes were found in the BF of infected chickens 48 times, i. e. in $40.3 \%$ of the birds, the mean Is being 0.79 .

In the thymus, monocellular necroses of lymphocytes and reticular epithelial cells with subsequent reduction in cellularity of both the cortex and medulla of thymic lobules were signs of regressive changes. Frequent findings were foci of cellular detritus. Hyperplasia and hypertrophy of Hassall's corpuscles and nests of granulocytes and erythrocytes in the medulla were an accompanying phenomenon of the regressive changes. The afore-mentioned changes in the thymus were observed 29 times, i. e. in $24.4 \%$ of the birds, the mean Is being 0.48 .
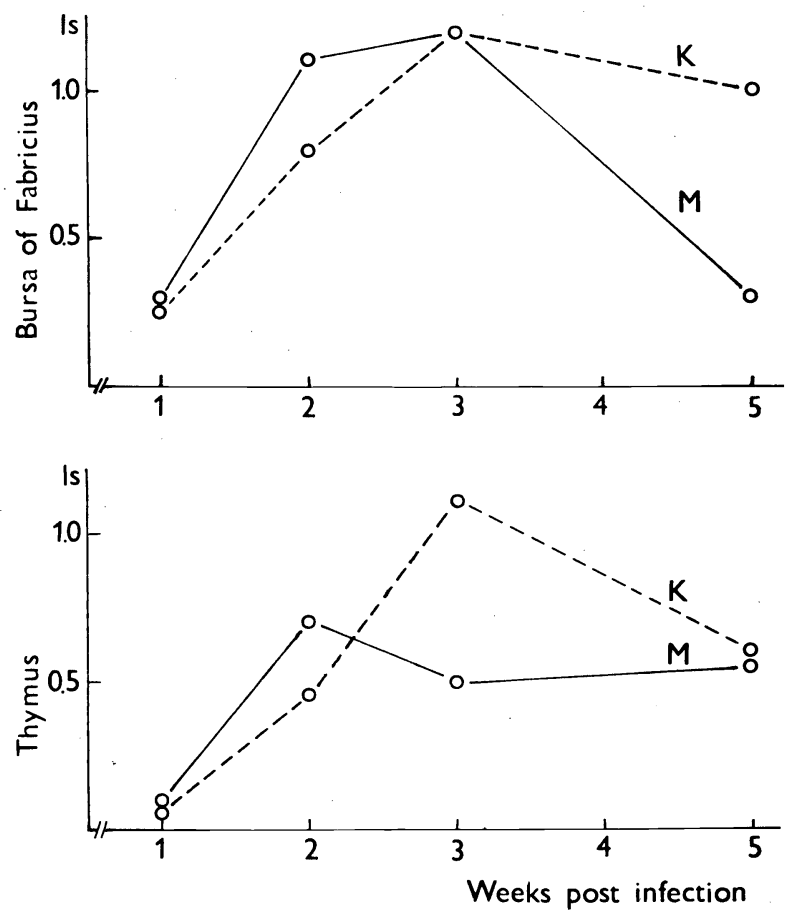

Fig. 1: Dynamics of immunosuppressive changes in the central lymph organs of chickens BrL p. i. with isolates $M$ and $\mathrm{K} M D V$

The spleen was the organ least affected with cytolytic changes. They became most apparent in the 2nd week p. i. and were observed 15 times, i. e. in $12.6 \%$ of the birds, the mean Is being 0.18 .

Out of a total of 357 lymphoid organ samples from the infected chickens 92 showed morphological evidence of immunosuppression. The mean Is was 0.48 . Immunosuppressive changes were found in a total of $62(52.1 \%)$ infected chickens.

Infection with MDV Isolate $\mathrm{K}$

Microscopic MD-specific changes were diagnosed in the skin of $17(14.4 \%)$ chickens, gonads of $14(11.9 \%)$ and in the skin of $1(0.85 \%)$ bird. On the whole, they were found in $3.87 \%$ out of 826 tissue samples examined and in $23.7 \%$ out of 118 infected chickens examined. 
Regular findings in addition to the common cutaneous MD-changes were feather-pulp changes (Plate XXVI., Fig. 2). Conspicious findings were an extended capillary network and mixed cellulization of the thin mesenchymal reticulum of the medulla, particularly around the veins. The intensity of cutaneous changes was direproportional to the size of dose and to the post-infection time. The changes in the gonads were of the same character as those observed after infection with isolate $M$, but their incidence was transient, peaking in the 2 nd week and no longer observed in the 5th week p. $i$. The changes in the spleen were characterized by hyperplasia of reticular and lymphoid cells and by congestion.

Evaluation of the regressive changes of the central lymphoid organs, showing the same morphological character as in the previous experiment, is presented graphically in Fig. 1 .

In the BF the lesions were more intense, being classified mostly as Si degree 3. A marked finding was inflammatory reaction in the affected lymphoid follicles (Plate XXVII., Fig. 4). Not uncommon was Si degree 4, characterized by lymphocyte depletion and follicular fibrosis (Fig. 5). The morphological immunosuppressive changes were detected 52 times, i. e. in $44.1 \%$ of the infected chickens, the mean Is being 0.79 .

In the thymus the result of evaluation was similar to that recorded for the $\mathrm{BF}$. In extreme instances (Si 4 ) the cortex of the lobules was almost free of lymphocytes (Fig. 6), whereas the medulla was diffusely infiltrated with lymphoid cells. This finding was designated by us as situs inversus. The thymic changes were observed 37 times, i. e. $31.4 \%$ of the infected chickens, the mean Is being 0.56 .

In the spleen the degree of cytolytic changes was only slightly higher than in the chickens infected with isolate $M$. The cytolytic changes were observed also in the germinal centres. They were found 25 times, i. e. in $21.2 \%$ of the infected chickens, the mean Is being 0.29 .

Out of a total of 354 lymphoid organ samples from the infected chickens, $114(32.2 \%)$ showed microscopic morphological evidence of immunosuppression. The mean Is was 0.54 . The immunosuppressive changes were found in $67(65.8 \%)$ infected chickens.

\section{Discussion}

From the results of experimental infection it appears that both isolate $\mathrm{K}$ and isolate $M$ were moderately pathogenic for susceptible $\mathrm{BrL}$ chickens. Isolate $\mathrm{K}$ produced inflammation of feather pulp and fewer lymphoproliferative changes (17 chickens) and is apparently less excreted to the environment than isolate $M$ (27 chickens). The cutaneous changes observed represent reaction to the presence of viral antigen (Lapen et al. 1971). These lesions are a proof of fully productive replication of the isolates and of their ability to spread to the environment (Jurajda 1971). Changes suggestive of pulpitis as found here after infection with isolate $\mathrm{K}$ have not been described in the relevant literature before. Payne (1985) and Moriguchi et al. (1987) have mentioned occasional lymphoid infiltrates in the feather pulp of chickens with MD but without specifying their character. In our view, these changes are part of $M D$-specific changes. We do not regard them as direct evidence of pathogenicity, they did not develop into marked pathological lesions and are only a manifestation of MDV infection (Halouzka 1981).

Type C minute lymphoid infiltrations in the nerves (Payne and Biggs 1967) observed by us after infection with isolate $M$ are signs of pathogenicity of the 
isolated virus. In the relevant literature, perineural infiltrations have been related to infections with non-oncogenic viruses (Schat 1981) and turkey herpes virus (Benda and Hložánek 1975). Nerves and gonads are reportedly the most frequently affected organs in the initial phases of MD (Payne 1985), which is in keeping with our observations.

Splenomegaly observed in our two experiments provides evidence of the replication and spread of the virus in the body. It is caused by proliferation of stroma cells and B-dependent lymphoid tissue and is a general sign of viraemia (Schat 1987).

Cytolytic changes in lymphoid organs are one of possible consequences of infection of lymphocytes and reticular cells with $M D$ viruses; they are more affected by host factors, and the initial target cells are predominantly B-lymphocytes (Calnek 1986), which is also an explanation of the fact that the BF was affected more than other organs. Cytolysis of lymphoid organs with. subsequent immunosuppression has been associated with oncogenicity of the virus, and low-oncogenicity strains have been reported to produce less damage to lymphoid organs than highly oncogenic strains (Payne 1985).

If we regard the incidence of MD-specific lesions in the organs as a criterion of pathogenicity, then isolate $\mathrm{M}$ was more pathogenic for $\mathrm{BrL}$ chickens than isolate $\mathrm{K}$. However, the regular incidence of cytolytic changes in the central lymphoid organs and spleen during the pathogenesis of infection with both isolates has to be regarded as a further criterion of their pathogenicity. Isolate $\mathrm{K}$ exerted a stronger immunosuppressive effect than isolate $M$.

It can be concluded that isolate $M$ was more pathogenic from the viewpoint of induction of $\mathrm{MD}$-specific changes but exerted a weaker immunosuppressive effect. Isolate $\mathrm{K}$ produced only minute transitory $\mathrm{MD}$-specific changes but its pathogenicity lied in stronger immunosuppression. In our view, cytolytic changes produced in lymphoid organs by non-oncogenic MDV strains can be interpreted as one of the causes of the immunosuppressive state in poultry. Considering their ubiquity, they can exert adverse effects under certain conditions.

\section{Izolace a studium biologických vlastností neonkogenních kuřecích herpes- virü Markovy nemoci}

Práce se zabývá cytolytickými změnami lymfatických orgánů kuřat $\mathrm{BrL}$ po experimentální infekci terénnimi izoláty kuřecích neonkogenních virů $M D$ a jejich významem pro patogenitu MDV. Izolované kmeny $M$ a $\mathrm{K}$ byly aplikovány dvoudenním kuřatưm v odlišných dávkách $\left(10^{2}, 10^{3}\right.$ a $10^{4} \mathrm{PFU}$ na kuře). $\mathrm{V}$ intervalech za $1,2,3$ a 5 týdnů po infekci bylo 10 kuřat $\mathrm{z}$ každé skupiny utraceno a patomorfologicky vyšetřeno. Histopatologicky byly vyšetřovány lymfatické orgány, kủže, periferní nervy a gonády. Cytolytické změny lymfatických orgánủ byly hodnoceny kvantitativnè stupni imunosuprese od 0 do 4.

Kromě MD-specifických lymfoproliferativních změn způsobovaly izolované kmeny $M D V$ cytolytické změny lymfatických orgánů. Izolát $M$ byl z hlediska indukce lymfoproliferativních změn virulentnější, ale měl slabší cytolytické účinky. Naopak izolát $\mathrm{K}$ způsoboval jen nepatrné, přechodné lymfoproliferativní změny, ale výraznější cytolytické léze lymfatických orgánů.

Cytolytické změny lymfatických orgánů jsou považovány za kritérium patogenity izolovaných kmenů $\mathrm{MDV}$ a za jednu $\mathrm{z}$ možných př́čin imunosupresivních stavů. 


\section{Изоляция и изүчение биологических свойств неонкогенных күриных герпесвирусов болезни Марека}

В работе уделено внимание цитологическим изменениям лимфатических органов цыплят BrL после экспериментальной инфекции полученными в полевых условиях изолятами куриных неонкогенных вирусов MD и их значением для патогенности MDV. Изолированные штаммы М и К применяли цыплятам в возрасте двое суток различными дозами $\left(10^{2}, 10^{3}\right.$ и $10^{4}$ PFU на одного цыпленка). В интервале $1,2,3$ и 5 недель после инфекции 10 цыплят от каждой группы умерщвляли и патоморфологически иследовали. Гистопатологически исследовали лимфатические органы, кожу, периферийные нервы и половые железы. Цитологические изменения лимфатических органов оценивали количественно степенью иммуносупрессивностью от 0 до 4.

Помимо MD - специфических лимфопролиферативных изменений изолированные штаммы MDV вызвали изменения лимфатических органоз. Изолят M отличался с точки зрения индукции лимфопролиферативных изменений большей вирулентностью, однако более слабым цитологическим воздействием. В противовес этому, изолят К Вызывал лишь незначительные, временные лимфопролифератически изменения, но, В то же время, более выразительные цитологические расстройства функции лимфатических органов.

Цитологические изменения лимфатических органов следует считать критерием патогенности изолированных штаммов MDV и одной из возможных причин иммуносупрессивных состояний.

\section{References}

BENDA, V.-HLOŽÁNEK I.: Effect of Large Doses of Turkey Herpes Virus on Antibody Response in Chickens. Folia biol. (Praha), 21, 1975: 184-188

BIGGS, P. M.-PAYNE, L. N.: Transmission experiments with Marek's disease (fowl paralysis). Vet. Rec., 75, 1963: 117-119

CALNEK, B. W.: Marek's disease - A Model for Herpes Virus Oncology. Crit. Rev. Microbiol., 12, 1986: 293-320

HALOUZKA, R.: Kožní forma Markovy choroby kuřat. Ph. D. thesis, VŠV Brno, 1981, 114 p.

HALOUZKA, R.-JURAJDA V.: Morphological Signs of Immunosuppression in Poultry. Acta vet. Brno, 60, 1991:271-276

JURAJDA, V.: Př́tomnost a přežívání agens Markovy nemoci drůbeže $\mathrm{v}$ prachu. $\mathrm{Ph}$. $\mathrm{D}$. thesis, VŠV Brno, 1971, 152p.

JURAJDA, V.-HALOUZKA R.: Izolace a studium biologických vlastností neonkogenních kuřecích herpesvirů Markovy nemoci. 1. Charakterizace in vitro. Veter. Med. (Praha), 1991a, (in press)

JURAJDA, V.-HALOUZKA, R.: Izolace a studium biologických vlastností neonkogenních kuřecích herpesvirů Markovy nemoci. 2. Charakterizace in vivo. Veter. Med. (Praha), 1991b, (in press)

LAPEN, R. F.-KENZY, S. G.-PIPER, R. C.-SHARMA, J. M.: Pathogenesis of cutaneous Marek S 'disease in chickens. J. Natl. Cancer Inst., 47, 1971: 389-399

MORIGUCHI, R.-YOSHIDA, H.-FUJIMOTO, Y.-MIKAMI, T. -IZAWA, H.: Feather-Pulp Lesions in Chickens with Naturally Occurring Mark's Disease Symptoms. Avian Dis., 31, 1987: $156-168$

PAYNE, L. N.: Pathology. In: Marek's disease. Martinus Nijhoff Publ., Boston, ed. L. N. Payne, 1985: $43-76$

PAYNE, L. N.-BIGGS, P. M.: Studies on Marek's disease. II. Pathogenesis. J. Natl. Cancer Inst., 39, 1967: 281-302

SCHAT, K. A.: Role of the spleen in the pathogenesis of Marek's disease. Avian Pathol., 10, 1981: $171-182$ 
SCHAT, K. A.: Characteristics of the virus. In: Marek's disease. Martinus Nijhoff Publ., Boston, ed. L. N. Payne, 1985: 77-112

SCHAT, K. A.: Mark's disease: A model for protection against herpesvirus induced tumours. Cancer Surveys, 6, 1987: 1

WITTER, R. L.-SHARMA, J. M.-FADLY, A. M.: Pathogenicity of variant Marek's disease virus isolants in vaccinated and unvaccinated chickens. Avian Dis., 24, 1980: 210-232 
Plate XXVI.

Halouzka R. - Jurajda V.: Isolation: ... pp. 43-49.

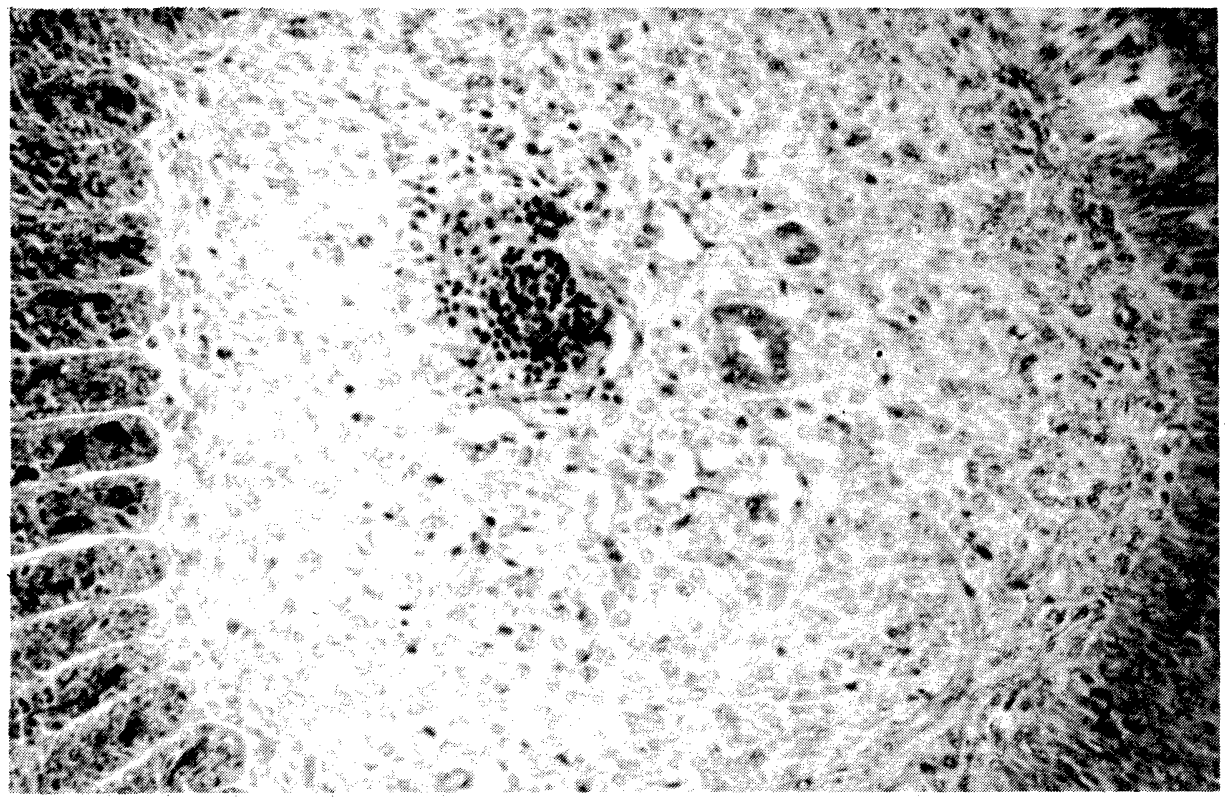

Fig. 2. A feather follicle with central mixed cellulization. HE, x 640 .

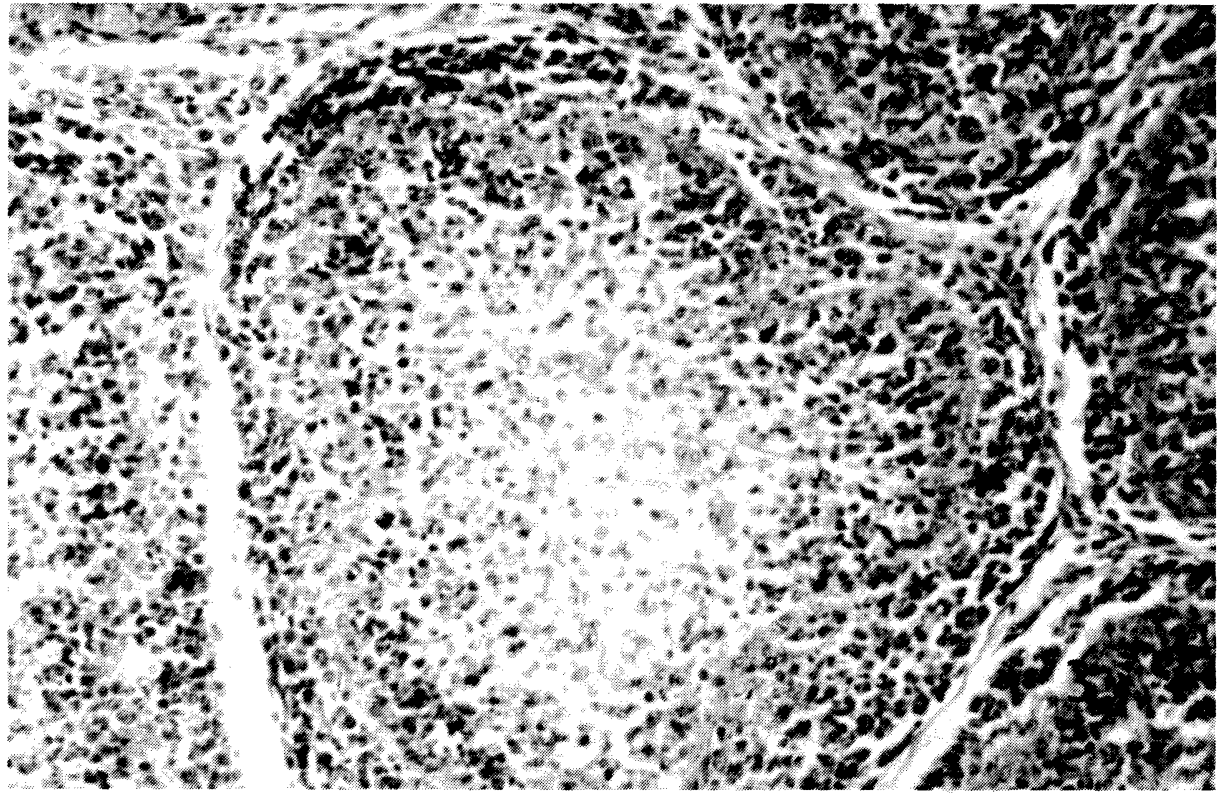

Fig. 3. Cytolysis and inflammation of the medulla of a lymphoid follicle in the bursa of Fabricius. $\mathrm{HE}, \mathrm{x} 640$. 


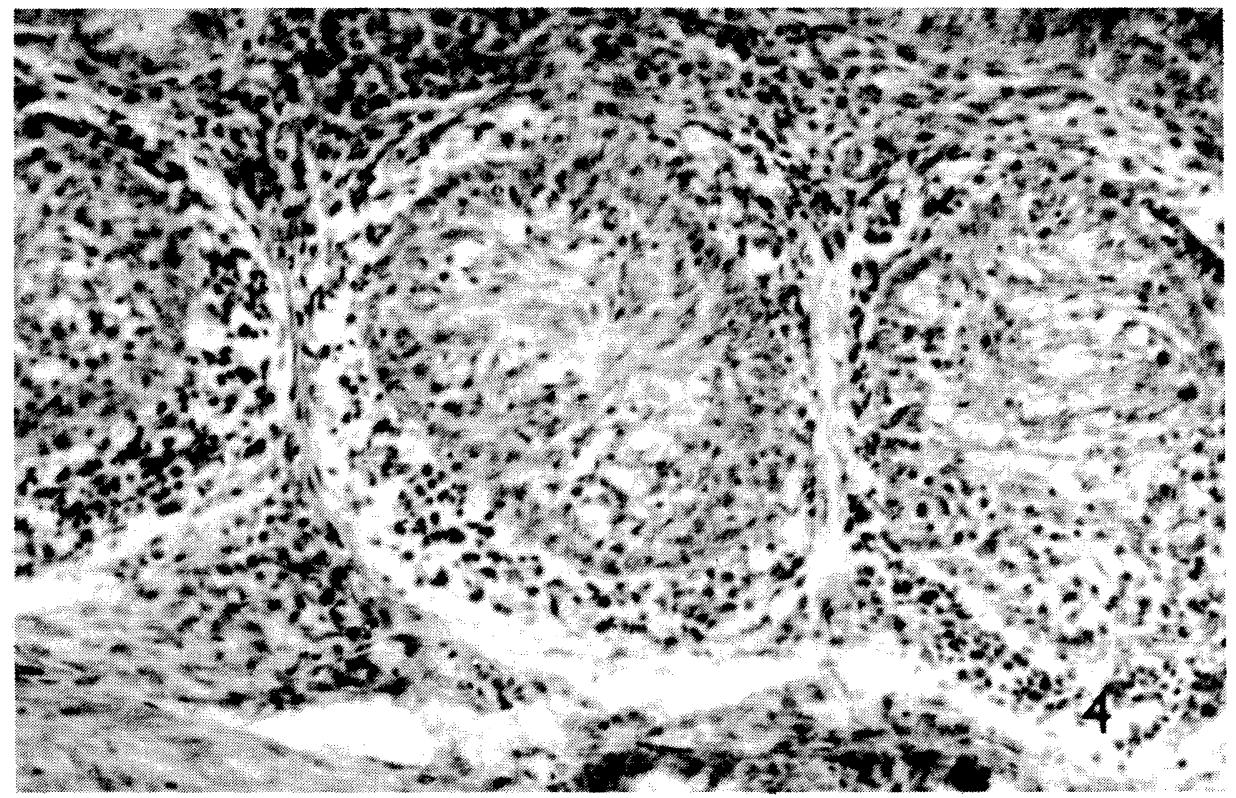

Fig. 4. Fibrosis of lymphoid follicles in the bursa of Fabricius. HE, x 640 .

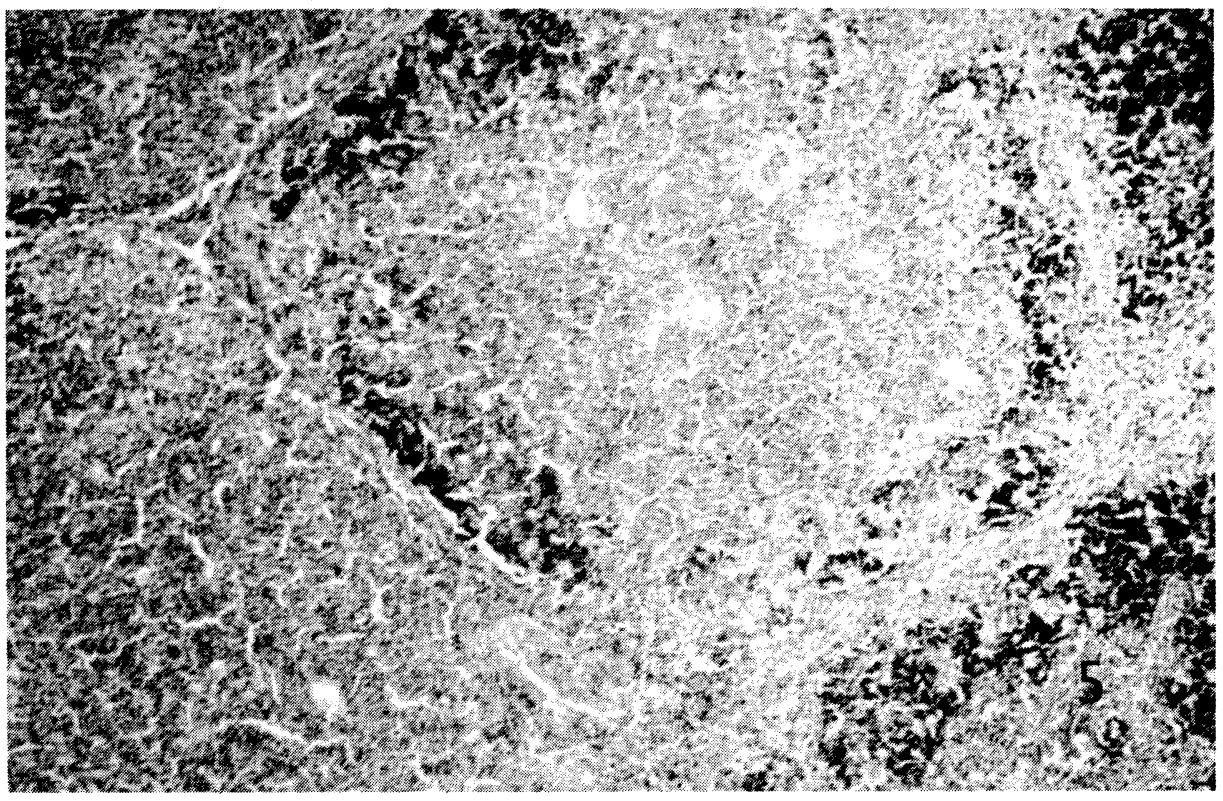

Fig. 5. Lymphocyte depletion in the thymic cortex. HE, $\times 250$. 